\title{
Pengaruh Perendaman Air Kelapa Dan Rootone F Terhadap Pertumbuhan Stek Tanaman Nilam (Pogstemon cablin, Benth)
}

\section{Effect Of Coconut Water Immersion And Rootone F On Growth Plant Cuttings Nilam (Pogstemon cablin, Benth)}

\author{
Irwanto $^{1}$, Rustam Baraq Noor ${ }^{2}$, Abdul Rofik ${ }^{2}$ \\ 1 Alumni Program Studi Agroteknologi, Fakultas Pertanian, Universitas Widya Gama Mahakam Jl. KH. Wahid \\ Hasyim, Sempaja, Samarinda, Kalimantan Timur, Indonesia \\ 2 Tenaga Pendidik Program Studi Agroteknologi, Fakultas Pertanian, Universitas Widya Gama Mahakam Jl. \\ KH. Wahid Hasyim, Sempaja, Samarinda, Kalimantan Timur, Indonesia
}

Diterima : 5 September 2019 Disetujui : 31 Desember 2019

Email :wanto@gmail.com, rusbnoor@gmail.com,birudaun83@gmail.com

\begin{abstract}
This study aims to determine the growth rate of patchouli (Pogostemon cablin, Benth) with $f$ rotoone administration and coconut water. The research was conducted on land peraktek Polytechnic State Agricultural Samarinda time for 2 months starting from the month of June to August 2016. The research design used was completely randomized design (CRD) with 6 treatments and 6 replications. treatment is $a 0=$ control, $a 1=$ Immersion Coconut Water with a concentration of 50\% pure coconut water, a2 = Immersion Coconut Water with a concentration of $100 \%$ pure coconut water, a3 = Immersion Rootone $F$ with a concentration of 50 grams, $a 4=$ basting mixture Coconut Water 50\% with a mixture of 50 grams Rootone F, basting mixture a5 = 100\% Coconut Water with a mixture Rootone F 50 grams. Results of analysis of variance showed that the Effects of Immersion Water Oil And Rootone F on Growth Cuttings Plant Patchouli (Pogostemon cablin, Benth) a very significant effect on the number of shoots 2 weeks after planting, plant height 2 WAP, 6 WAP, stem diameter 2 WAP, 4 WAP, 6 WAP and 8 WAP. real effect on the number of parameters shoots 4 WAP, 6 WAP, 8 WAP, plant height 4 and 8 WAP.
\end{abstract}

Keywords : F rotoone administration, coconut water and patchoul.

\section{PENDAHULUAN}

Tanaman nilam (Pogostemon cablin, Benth) merupakan salah satu tanaman perkebunan yang memiliki prospek ekonomi cukup cerah, hasil dari tanaman nilam adalah minyak nilam yang diperoleh dari proses penyulingan daun dan ranting tanaman nilam. Di Indonesia pengembangan tanaman nilam mempunyai tujuan ganda, disamping untuk meningkatkan pendapatan petani juga meningkatkanproduktivitas lahan kering.Berdasarkan laporan Market Essential Oil and Oleoresin (ITC), produksi nilam dunia mencapai 500 - 550 ton pertahun. Produksi Indonesia sekitar 450 ton pertahun, kemudian disusul Cina 50 - 80 ton pertahun. Produksi atsiri dunia yang didominasi Indonesia meliputi nilam, serai wangi, minyak daun cengkeh dan kenanga(Anonim, 2004).

Menurut Santoso (2007), pembibitan nilam dapat dilakukan di polybag. Keuntungan pembibitan di polybag antara lain lebih mudah melakukan perawatan dan pengontrolan, menghemat penggunaan bibit serta dapat mengurangi tingkat kematian akibat pemindahan ke kebun atau lahan.

Tanaman nilam jarang, bahkan hampir tidak pernah berbunga sehingga perbanyakan secara generatif tidak dilakukan. Pengembangan tanaman nilam dilakukan secara vegetatif dengan menggunakan stek cabang yang sudah berkayu dan mempunyai ruas-ruas pendek. Untuk mendapatkan stek yang baik, bahan stek berasal dari tanaman induk yang sehat, bebas dari hama penyakit serta tanaman induk berumur $6-12$ bulan(Rahardjo dan Wiryanto, 2003).

Perbanyakan tanaman nilam dilakukan dengan pengambilan stek dari tanaman induk yang berumur lebih dari satu tahun dan diambil dari ranting-ranting muda yang telah berkayu serta mempunyai banyak mata tunas. Perbanyakan tanaman nilam dilakukan dengan cara vegetatif, yakni dengan stek batang dan stek cabang (Rukmana, 2004).

Bibit tanaman nilam diperoleh dari perbanyakan stek batang. Bahan stek yang diambil berasal dari tanaman induk yang sudah berumur lebih dari 4 bulan. Ukuran stek yaitu 3 ruas dan panjangnya $15 \mathrm{~cm}$ serta daun dipangkas 
lebih dahulu dengan menyisakan $2-4$ helai daun muda (Amin, 2006).

Media merupakan salah satu faktor luar yang sangat berpengaruh terhadap keberhasilan pembibitan stek. Hal ini disebabkan media dalam pembibitan merupakan salah satu faktor yang sangat berperan terhadap pertumbuhan awal, terutama terbentuknya akar. Sebagian unsur hara yang dibutuhkan tanaman tersebut dipasok dari media tanam. Media tanam yang baik memiliki komposisi yang tepat. Komposisi media tanam mempunyai kemampuan menyediakan unsur hara yang dibutuhkan tanaman dalam menunjang kebutuhan hidup stek nilam. Media yang baik untuk pertumbuhan stek yaitu beraerasi baik dan bebas hama penyakit, mengandung cukup bahan organik dan mampu menahan air yang tinggi, sehingga air yang diperlukan selama pertumbuhan awal selalu terpenuhi (Hardjowigeno, 2003).

Pemacuan peningkatan pertumbuhan stek nilam dengan pengaplikasian zat pengatur tumbuh. Pemberian zat pengatur tumbuh diharapkan memperbaiki pertumbuhan tanaman seperti mempercepat pembentukan akar. Pengaruh zat pengatur tumbuh secara fisiologis dapat berpengaruh pada pertumbuhan tanaman. Air kelapa merupakan salah satu zat pengatur tumbuh alami yang lebih murah dan mudah didapatkan dan juga telah lama dikenal sebagai zat tumbuh.

ZPT adalah senyawa organik yang bukan hara (nutrien), yang dalam jumlah sedikit dapat dapat mendukung, menghambat dan dapat merubah proses fisiologi tumbuhan. ZPT terdiri dari lima yaitu auksin yang mempunyai kemampuan dalam mendukung perpanjangan sel, giberelin dapat menstimulasi pembelahan sel, pemanjangan sel atau keduanya, sitokinin mendukung terjadinya pembelahan sel, ethilen ber-peran dalam proses pematangan buah, dan asam absisat (Abidin, 1983). ZPT auksin secara garis besarnya dapat dibagi atas dua golongan, yaitu alami seperti urine sapi dan air kelapa muda dan sintesis (buatan) dengan merek dagang seperti Atonik, Dekamon, Rootone F, Root Up.

Air kelapa muda mengandung zat hara dan zat pengatur tumbuh yang diperlukan untuk perkembangan dan pertumbuhan tanaman. Menurut Juswardi (1998), air kelapa muda

\section{HASIL DAN PEMBAHASAN}

Hasil analisis sidik ragam menunjukkan bahwa Pengaruh Perendaman Air Kelapa Dan Rootone F Terhadap Pertumbuhan Stek Tanaman Nilam (Pogostemon cablin, Benth) berpengaruh sangat nyata pada jumlah tunas 2 MST, tinggi mengandung senyawa organik seperti vitamin $C$, vitamin $\mathrm{B}$, hormon auksin, giberelin dan sitokinin $5,8 \mathrm{mg} / \mathrm{L}$. Air kelapa muda juga mengandung air, protein, karbohidrat, mineral, vitamin, sedikit lemak, Ca dan P.

Zat Pengatur Tumbuh Rootone F merupakan ZPT sintetis yang berbentuk serbuk, berwarna putih, yang berguna untuk mempercepat dan memperbanyak keluarnya akar-akar baru, karena mengandung bahan aktif dari hasil formulasi beberapa hormon tumbuh akar yaitu naftalenasetamida $0,067 \%, 2$ metil 1 naftalenasetamida $0,013 \%, 2$ metil 1 naftalen asetat $0,033 \%$, indole 3 butirat (IBA) $0,057 \%$, dan tiram 4\% (Rismunandar, 1992).

\section{BAHAN DAN METODE}

Bahan yang digunakan dalam penelitian ini yaitu: setek tanaman nilam, air kelapa, rootone $\mathrm{F}$, air dan polybag. Penelitian dilakukan penelitian di jalan Samartulangi di lahan peraktek Politeknik Pertanian Negeri Samarinda Sungai Keledang Kegiatan ini di lakukan selama \pm 2 bulan, terhitung mulai dari bulan Juni sampai dengan bulan Agustus tahun 2016. Waktu yang diperlukan dalam penelitian ini adalah 3 bulan, terhitung dari tanggal 1 Juni sampai dengan tanggal 30 Agustus 2016 meliputi persiapan, pelaksanaan dan penyusunan laporan. Penelitian menggunakan Rancangan Acak Lengkap (RAL) faktorial yang terdiri dari 6 perlakuan dan 6 kali ulangan, yaitu: $\mathrm{a}_{0}$ : kontrol (tanpa perlakuan), $\mathrm{a}_{1}$ : perendaman air kelapa dengan konsentrasi 50\% air kelapa murni, $\mathrm{a}_{2}$ : perendaman air kelapa dengan konsentrasi $100 \%$ air kelapa murni, a perendaman rootone $\mathrm{f}$ dengan konsentrasi 50 gram, a4: pengolesan campuran air kelapa 50\% dengan campuran rootone $\mathrm{f} 50$ gram dan as:pengolesan campuran air kelapa $100 \%$ dengan campuran rootone f 50 gram. Kegiatan penelitian meliputi : persiapan media tanam, perlakuan, penaman, pemeliharaan, pengambilan data dan pengolahan data dengan sidik ragam. Jika dari hasil sidik ragam $\mathrm{F}$ hitung berpengaruh nyata, maka dilakukan uji Beda Nyata Terkecil (BNT) pada taraf 0,05.

tanaman 2 MST, 6 MST, diameter batang 2 MST, 4 MST, 6 MST dan 8 MST. berpengaruh nyata pada parameter jumlah tunas 4 MST, 6 MST, 8 MST, tinggi tanaman 4 MST dan 8 MST. Abidin (2003), bahwa hubungan dari pertumbuhan dan kadar auksin adalah sama pada akar, daun dan tunas yaitu auksin merangsang pada kadar rendah sebaliknya menghambat pada 
kadar tinggi, sehingga dengan pemberian kosentrasi rootone $\mathrm{F}$ yang tepat akan meningkatkan pertumbuhan tunas-tunas baru. Selain itu ZPT Rootone F yang diberi sesuai kosentrasi yang dibutuhkan tanaman, sehingga dalam keseimbangan dengan auksin di dalam tubuh tanaman yang mempunyai peranan penting dalam meningkatkan protein, maka akan mempengaruhi proses pertumbuhan.

Tabel 1. Pengaruh Perendaman Air Kelapa Dan Rootone F Terhadap Pertumbuhan Stek Tanaman Nilam (Pogostemon cablin, Benth) Rata-rata Tinggi Tanaman 2 MST (cm).

\begin{tabular}{cc}
\hline Perlakuan & Rataan \\
\hline $\mathrm{a}_{0}$ & $2,17 \mathrm{~d}$ \\
$\mathrm{a}_{1}$ & $2,33 \mathrm{~d}$ \\
$\mathrm{a}_{2}$ & $3,33 \mathrm{bc}$ \\
$\mathrm{a}_{3}$ & $3,83 \mathrm{ab}$ \\
$\mathrm{a}_{4}$ & $4,17 \mathrm{a}$ \\
$\mathrm{a}_{5}$ & $3,17 \mathrm{c}$ \\
\hline
\end{tabular}

Keterangan : Nilai rata-rata yang diikuti oleh huruf yang sama menunjukkan berbeda sangat nyata pada uji BNT taraf 5\% 2 MST (BNT A =0,65).

Tabel 2. Pengaruh Perendaman Air Kelapa Dan Rootone F Terhadap Pertumbuhan Stek Tanaman Nilam (Pogostemon cablin, Benth) Rata-rata Tinggi Tanaman 4 MST (cm).

\begin{tabular}{cc}
\hline Perlakuan & Rataan \\
\hline $\mathrm{a}_{0}$ & $6,00 \mathrm{c}$ \\
$\mathrm{a}_{1}$ & $7,33 \mathrm{~b}$ \\
$\mathrm{a}_{2}$ & $7,17 \mathrm{~b}$ \\
$\mathrm{a}_{3}$ & $7,50 \mathrm{~b}$ \\
$\mathrm{a}_{4}$ & $9,00 \mathrm{a}$ \\
$\mathrm{a}_{5}$ & $7,00 \mathrm{~b}$ \\
\hline
\end{tabular}

Keterangan : Nilai rata-rata yang diikuti oleh huruf yang sama menunjukkan berbeda nyata pada uji BNT taraf 5\% 4 MST (BNT A = 0,78).

Tabel 3. Pengaruh Perendaman Air Kelapa Dan Rootone F Terhadap Pertumbuhan Stek Tanaman Nilam (Pogostemon cablin, Benth) Rata-rata Tinggi Tanaman 6 MST (cm).

\begin{tabular}{cc}
\hline Perlakuan & Rataan \\
\hline $\mathrm{a}_{0}$ & $7,00 \mathrm{c}$ \\
$\mathrm{a}_{1}$ & $8,33 \mathrm{~b}$ \\
$\mathrm{a}_{2}$ & $8,17 \mathrm{~b}$ \\
$\mathrm{a}_{3}$ & $8,50 \mathrm{~b}$ \\
$\mathrm{a}_{4}$ & $10,00 \mathrm{a}$ \\
$\mathrm{a}_{5}$ & $8,00 \mathrm{~b}$ \\
\hline
\end{tabular}

Keterangan : Nilai rata-rata yang diikuti oleh huruf yang sama menunjukkan berbeda sangat nyata pada uji BNT taraf 5\% 6 MST (BNT A = 0,73).

Tabel 4. Pengaruh Perendaman Air Kelapa Dan Rootone F Terhadap Pertumbuhan Stek Tanaman Nilam (Pogostemon cablin, Benth) Rata-rata Tinggi Tanaman 8 MST $(\mathrm{cm})$.

\begin{tabular}{cc}
\hline Perlakuan & Rataan \\
\hline $\mathrm{a}_{0}$ & $6,00 \mathrm{c}$ \\
$\mathrm{a}_{1}$ & $7,33 \mathrm{~b}$ \\
$\mathrm{a}_{2}$ & $7,17 \mathrm{~b}$ \\
$\mathrm{a}_{3}$ & $7,50 \mathrm{~b}$ \\
$\mathrm{a}_{4}$ & $9,00 \mathrm{a}$ \\
$\mathrm{a} 5$ & $7,00 \mathrm{~b}$ \\
\hline
\end{tabular}

Keterangan : Nilai rata-rata yang diikuti oleh huruf yang sama menunjukkan berbeda nyata pada uji BNT taraf 5\% 8 MST (BNT A = 0,69). 
Tabel 5. Pengaruh Perendaman Air Kelapa Dan Rootone F Terhadap Pertumbuhan Stek Tanaman Nilam (Pogostemon cablin, Benth) Rata-rata Diameter Batang 2 MST (mm).

\begin{tabular}{cc}
\hline Perlakuan & Rataan \\
\hline $\mathrm{a}_{0}$ & $2,41 \mathrm{~b}$ \\
$\mathrm{a}_{1}$ & $2,90 \mathrm{a}$ \\
$\mathrm{a}_{2}$ & $3,06 \mathrm{a}$ \\
$\mathrm{a}_{3}$ & $3,08 \mathrm{a}$ \\
$\mathrm{a}_{4}$ & $3,17 \mathrm{a}$ \\
$\mathrm{a}_{5}$ & $3,01 \mathrm{a}$ \\
\hline
\end{tabular}

Keterangan : Nilai rata-rata yang diikuti oleh huruf yang sama menunjukkan berbeda sangat nyata pada uji BNT taraf 5\% 2 MST (BNT A =0,30).

Tabel 6. Pengaruh Perendaman Air Kelapa Dan Rootone F Terhadap Pertumbuhan Stek Tanaman Nilam (Pogostemon cablin, Benth) Rata-rata Diameter Batang 4 MST (mm).

\begin{tabular}{cc}
\hline Perlakuan & Rataan \\
\hline $\mathrm{a}_{0}$ & $2,91 \mathrm{c}$ \\
$\mathrm{a}_{1}$ & $3,38 \mathrm{~b}$ \\
$\mathrm{a}_{2}$ & $3,54 \mathrm{ab}$ \\
$\mathrm{a}_{3}$ & $3,58 \mathrm{ab}$ \\
$\mathrm{a}_{4}$ & $3,69 \mathrm{a}$ \\
$\mathrm{a}_{5}$ & $3,54 \mathrm{ab}$ \\
\hline
\end{tabular}

Keterangan : Nilai rata-rata yang diikuti oleh huruf yang sama menunjukkan berbeda sangat nyata pada uji BNT taraf 5\% 4 MST (BNT A = 0,27).

Tabel 7. Pengaruh Perendaman Air Kelapa Dan Rootone F Terhadap Pertumbuhan Stek Tanaman Nilam (Pogostemon cablin, Benth) Rata-rata Diameter Batang 6 MST (mm).

\begin{tabular}{cc}
\hline Perlakuan & Rataan \\
\hline $\mathrm{a}_{0}$ & $3,42 \mathrm{c}$ \\
$\mathrm{a}_{1}$ & $3,88 \mathrm{~b}$ \\
$\mathrm{a}_{2}$ & $4,04 \mathrm{ab}$ \\
$\mathrm{a}_{3}$ & $4,08 \mathrm{ab}$ \\
$\mathrm{a}_{4}$ & $4,18 \mathrm{a}$ \\
$\mathrm{a}_{5}$ & $4,05 \mathrm{ab}$ \\
\hline
\end{tabular}

Keterangan : Nilai rata-rata yang diikuti oleh huruf yang sama menunjukkan berbeda sangat nyata pada uji BNT taraf 5\% 6 MST (BNT A = 0,25).

Tabel 8. Pengaruh Perendaman Air Kelapa Dan Rootone F Terhadap Pertumbuhan Stek Tanaman Nilam (Pogostemon cablin, Benth) Rata-rata Diameter Batang 8 MST (mm).

\begin{tabular}{cc}
\hline Perlakuan & Rataan \\
\hline $\mathrm{a}_{0}$ & $3,42 \mathrm{~d}$ \\
$\mathrm{a}_{1}$ & $3,88 \mathrm{c}$ \\
$\mathrm{a}_{2}$ & $4,04 \mathrm{bc}$ \\
$\mathrm{a}_{3}$ & $4,08 \mathrm{bc}$ \\
$\mathrm{a}_{4}$ & $4,18 \mathrm{~b}$ \\
$\mathrm{a}_{5}$ & $4,54 \mathrm{a}$ \\
\hline
\end{tabular}

Keterangan : Nilai rata-rata yang diikuti oleh huruf yang sama menunjukkan berbeda sangat nyata pada uji BNT taraf 5\% 8 MST (BNT A =0,25).

Ditambahkan Harjadi (1996), bahwa pada bagian tanam yang aktif terdapat auksin yang disintesis sehingga dapat memacu pertumbuhan sel-sel yang terdapat pada jaringan meristem, dapat dikatakan bahwa bahan aktif yang terkandung di dalam zat pengatur tumbuh Rootone $\mathrm{F}$ dapat bergerak dari satu bagian ke bagian lainnya sehingga mempunyai peranan dalam pembelahan sel, dan pada akhirnya akan mempengaruhi proses pertumbuhan tanaman, 
kemudian pengaruh nyata ini diduga bahwa pemberian ZPT rootone $\mathrm{F}$ dapat meningkatkan sintetis protein di dalam tanah sehingga akan menjamin sel-sel baru yang memerlukan protein, dinyatakan Abidin (2003) lagi bahwa auksin berpengaruh terhadap perkembangan sel dengan meningkatkan tekanan osmotik sel terhadap air yang menyebabkan berkurangnya dinding sel, meningkatkan sintetis protein, meningkatkan plastisitas dan perkembangan sel, sebagai akibat pengaruh auksin ini sel-sel tersebut mengembang dan memanjang serta menyerap air, dengan demikian dihasilkan sel-sel yang besar dengan vakuola yang besar pula.

Savitri (1995) telah melakukan analisis hormon pada air kelapa muda, ternyata dalam air kelapa muda terdapat Giberelin $(0,460 \mathrm{ppm} \mathrm{GA}$, $0,255 \mathrm{ppm} \mathrm{GA}_{5}$ dan $0,053 \mathrm{ppm} \mathrm{GA}_{7}$ ), Sitokinin (0,441 ppm Kinetin dan 0,247 ppm Zeatin) dan Auksin (0,237 ppm IAA). Kandungan hormon sitokinin (kinetin dan zeatin) dan auksin (IAA) pada air kelapa diduga yang menyebabkan meningkatnya semua parameter pertumbuhan stek. Menurut Janick (1979), kapasitas bagian vegetatif menghasilkan akar diakibatkan oleh interaksi faktor-faktor yang melekat (inherent) pada tanaman dengan faktor lain seperti zat-zat yang dapat diangkut oleh tanaman dan diproduksi dalam kuncup, yakni auksin, karbohidrat, senyawasenyawa nitrogen, vitamin dan berbagai senyawa lain yang belum berhasil diidentifikasi. Disebutkan juga, bahwa zat yang berinteraksi dengan auksin dinamakan rooting cofactor yang menjadi pelatuk terjadinya perakaran. Sampai saat ini, baru auksin yang dianggap dapat menginduksi tumbuhnya akar pada stek. Krisnamoorthy (1981) memperkuat pendapat tersebut di atas bahwa berdasarkan percobaan-percobaan yang telah dilakukan selama ini ternyata bahwa dari sekian banyak zat pengatur tumbuh yang ada, hanya

\section{KESIMPULAN}

Pengaruh Perendaman Air Kelapa Dan Rootone F Terhadap Pertumbuhan Stek Tanaman Nilam (Pogostemon cablin, Benth) yang terbaik terhadap jumlah daun, jumlah golongan auksin (sintetik maupun alamiah) yang mampu menginduksi perakaran stek.

Tumbuhnya tunas pada stek sangat diperlukan untuk mendorong terjadinya perakaran stek. Pembentukan akar tidak akan terjadi bila seluruh tunas dihilangkan atau dalam keadaan dorman, hal ini terjadi karena tunas berperan sebagai sumber auksin yang menstimulir pembentukan akar, terutama bila tunas mulai tumbuh (Leopold 1955). Tumbuhnya tunas pada stek sangat diperlukan untuk mendorong terjadinya perakaran stek. Pembentukan akar tidak akan terjadi bila seluruh tunas dihilangkan atau dalam keadaan dorman, hal ini terjadi karena tunas berperan sebagai sumber auksin yang menstimulir pembentukan akar, terutama bila tunas mulai tumbuh (Leopold 1955).

Pertumbuhan tunas pada stek yang diberi air kelapa lebih cepat dan serempak, hal ini diduga karena adanya kandungan sitokinin yang terdiri dari kinetin dan zeatin pada air kelapa. Menurut Leopold (1955), adanya sitokinin memungkinkan terjadinya pembentukan tunas dengan segera dan serempak, mencegah terjadinya pengguguran daun yang lebih dini, terjadinya pembelahan dan pembesaran sel yang lebih aktif.

Hasil penelitian pengaruh pemberian air kelapa pada stek nilam yang dilakukan Rusmayasari (2006) menunjukkan hasil yang sama dengan penelitian ini dimana pemberian air kelapa mampu meningkatkan parameter pertumbuhan pendapat Hartmann et al. (1997), penggunaan zat pengatur tumbuh seperti IAA, IBA dan NAA dapat mendorong inisiasi akar, mempercepat pembentukan akar, mening-katkan persen stek berakar, meningkatkan jumlah dan kualitas akar dan meningkatkan keseragaman perakaran. Walaupun demikian pemberian zat pengatur tumbuh tersebut pada berbagai konsentrasi dapat berbeda-beda untuk setiap jenis tanaman, bahkan berbeda pula antar varietas dalam satu jenis.

tunas, tinggi tanaman dan diameter batang dicapai oleh perlakuan $\mathrm{a}_{4}$ (stek tanaman nilam diolesi dengan campuran Air Kelapa dan Rootone F dengan konsentrasi 50\% Air Kelapa dan 50 gram Rootone F).

\section{DAFTAR PUSTAKA}

Abidin, Z, 1987. Dasar- dasar Pengetahuan Tentang Zat Pengatur Tumbuh. Yasaguna Bandung.
Abidin Z. 1993. Dasar-Dasar Pengetahuan Tentang Zat Pengatur Tumbuh. Percetakan Angkasa, Bandung. 
M. 2006

Nilam,

(Online),(http://www.riaupos.com

WAP:wap.riaupos.com, diakses 09 Maret 2016).

Anonim. 2004. Ditjen Bina Produksi Perkebunan.

Hardjowigeno, S. 2003. Ilmu Tanah. Jakarta : Penerbit Akademika Pressindo.

Harjadi,S.S.1996. Pengantar Agronomi.Gramedia. Jakarta.87 hal.

Hartmann HT, Kester DE, Davies FT, Geneve RL. 1997. Plant Propagation : Principles and Practice. Ed ke-6. Englewood Cliffs, New Jersey : Prentice Hall.

Hidayat A. 2006. Pengaruh Konsentrasi Dan Lama Perendaman Air Kelapa Terhadap Pertumbuhan Vegetatif Stek Lada (Piper Nigrum L). Fakultas Pertanian Universitas Mulawarman Samarinda. (Tidak dipublikasikan).

Janick J. 1979. Horticultural Science. San Fransisco : W.H. Freeman and Company.

Khrisnamoorthy HN. 1981. Plant Growth Substance Including Application in Agriculture. New Delhi : Tata McGraw-Hill Publishing Company Ltd.

Leopold AL. 1955. Auxins and Plant Growth. Barkeley, Los Angeles : Univ.of California Press.

Mangun, H.M.S. 2006.Nilam. Jakarta: Penebar Swadaya.

Parnata, AS. 2004. Pupuk Organik Cair, Aplikasi dan Manfaatnya. Agromedia Pustaka. Jakarta. 